\title{
UNDERSTANDING IDEA OF CURRICULUM 2013 AND ITS CONSISTENCY ON DEVELOPING CURRICULUM DOCUMENT AT LEVEL OF EDUCATION UNIT (KTSP) AT PRIMARY SCHOOL LEVEL \\ Oleh: \\ Prihantini $^{1}$ \\ Universitas Pendidikan Indonesia
}

\begin{abstract}
This study is based on various issues of Curriculum 2013, both in terms of teacher readiness to accept the Curriculum 2013, an understanding of the idea of Curriculum 2013, as well as in the implementation of teaching and learning. In the curriculum development theory, curriculum ideas are an important component that the curriculum development team needs to understand, so that the development of curriculum documents composed reflects continuity with curriculum ideas. The purpose of this study is to describe and explore the understanding of principals and teachers about the idea of Curriculum 2013 and its consistency on developing Education Unit Level Curriculum (KTSP) at elementary school in Sukalarang sub-district, Sukabumi regency. The research method applied is qualitative research with descriptive exploratory approach. The conclusions of the study are: (1) the understanding of principals and teachers about the idea of the Curriculum 2013 at the know stage, the understanding that curriculum ideas have consistency in the development of the Education Unit Level Curriculum (KTSP) document is not yet owned; (2) the development of KTSP document shows no consistency between the idea of Curriculum 2013 with the documents of Book I KTSP, Book II KTSP, and Book III KTSP; (3) the problems faced by school principals and teachers in relation to the Curriculum 2013 is assessment of learning, both with regard to the techniques and types of assessment and techniques of administering the results of the assessment.Recommendations are proposed to policy makers that training strategies need to be changed from "theory oriented" to "practice oriented" and need to be varied in implementation at the Kecamatan or Cluster levels and enhanced effectiveness of curriculum counseling 2013. For principals and teachers expected to disseminate the 2013 Curriculum should be supported by presenting expert resources during the workshop, Principal Working Group (K3S) and Teachers Working Group (KKG) activities, so that the understanding of the idea of Curriculum 2013 that has not been assessed in training at the Provincial or District level can be strengthened and strengthened during the activities of $K 3 S$ and $K K G$.
\end{abstract}

Keyword: Idea of Curriculum 2013, consistency, curriculum development team, KTSP documents, Principal Working Group (K3S), Teachers Working Group (KKG).

Abstrak: Penelitian ini dilatar belakangi adanya berbagai permasalahan Kurikulum 2013, baik dari sisi kesiapan guru menerima Kurikulum 2013, pemahaman terhadap ide Kurikulum 2013, maupun dalam implementasi pembelajaran. Dalam landasan teori pengembangan kurikulum, ide kurikulum merupakan komponen penting yang perlu dipahami oleh tim pengembang kurikulum, sehingga pengembangan dokumen kurikulum yang disusun mencerminkan kesinambungan dengan ide kurikulum. Adanya sejumlah permasalahan tersebut, maka penelitian ini bertujuan untuk menggambarkan dan meng-eksplorasi pemahaman kepala sekolah dan guru tentang ide Kurikulum 2013 dan konsistensinya terhadap pengembangan dokumen Kurikulum Tingkat Satuan Pendidikan (KTSP) jenjang Sekolah Dasar di Kecamatan Sukalarang Kabupaten Sukabumi. Metode penelitian yang diterapkan adalah penelitian kualitatif dengan pendekatan deskriptif eksploratori. Kesimpulan hasil penelitian adalah: (1) pemahaman kepala sekolah dan guru tentang ide Kurikulum 2013 baru pada taraf kenal dan tahu, pemahaman bahwa ide kurikulum memiliki konsistensi dalam pengembangan dokumen Kurikulum Tingkat Satuan Pendidikan (KTSP) belum dimiliki; (2) dokumen Kurikulum Tingkat Satuan Pendidikan (KTSP)

\footnotetext{
${ }^{1}$ Universitas Pendidikan Indonesia, Email: prihantini@upi.edu
} 
yang dikembangkan menunjukkan tidak ada konsistensi antara ide Kurikulum 2013 dengan dokumen Buku I KTSP, Buku II KTSP, dan Buku III KTSP; (3) permasalahan yang dihadapi kepala sekolah dan guru berkaitan dengan Kurikulum 2013 adalah masalah penilaian, baik berkaitan dengan teknik dan jenis penilaian maupun teknik pengadministrasian hasil penilaian. Rekomendasi diusulkan kepada pengambil kebijakan, bahwa strategi pelatihan perlu diubah dari bersifat "theory oriented" kearah "practice oriented" dan perlu divariasikan pelaksanaannya di tingkat Kecamatan atau Gugus Sekolah serta ditingkatkan efektifitas pola pendampingan Kurikulum 2013. Bagi kepala sekolah dan guru diharapkan dalam mendiseminasikan Kurikulum 2013 perlu didukung dengan menghadirkan nara sumber ahli pada saat kegiatan workshop, kegiatan K3S atau KKG, sehingga pemahaman ide Kurikulum 2013 yang belum terkaji dalam pelatihan di tingkat Provinsi atau Kabupaten dapat diperkuat dan dimantapkan pada saat kegiatan Kelompok Kerja Kepala Sekolah (K3S) dan Kelompok Kerja Guru (KKG).

Kata Kunci: Ide Kurikulum 2013, konsistensi, tim pengembang kurikulum, dokumen KTSP, Kelompok Kerja Kepala Sekolah (K3S), Kelompok Kerja Guru (KKG).

\section{PENDAHULUAN}

Secara historis kurikulum di Indonesia telah mengalami beberapa kali perubahan, perubahan terakhir adalah lahirnya Kurikulum 2013, dengan ketetapan kebijakan kurikulum dikembangkan pada tingkat satuan pendidikan. Kebijakan tersebut tercantum dalam Undang-undang Nomor 20 Tahun 2003 pasal 38 ayat (2) bahwa kurikulum pendidikan dasar dan menengah dikembangkan sesuai dengan relevansinya oleh setiap kelompok atau satuan pendidikan dan komite sekolah/madrasah dibawah pengawasan dinas pendidikan atau kantor Departemen Agama Kabupaten/Kota untuk pendidikan dasar dan Provinsi untuk pendidikan menengah. Ketentuan tersebut dipertegas dalam Peraturan Pemerintah Nomor 19 tahun 2005 pasal 17 ayat (1) dan ayat (2) yang pada intinya sekolah dan komite sekolah mengembangkan kurikulum tingkat satuan pendidikan (KTSP).

Kebijakan pemberlakuan Kurikulum 2013 ditetapkan melalui Keputusan Mendikbud Nomor 57 Tahun 2014, dilengkapi dengan Keputusan Mendikbud Nomor 67 Tahun 2013 tentang Kerangka Dasar dan Struktur Kurikulum SD/MI dan Nomor 61 Tahun 2014 tentang Pedoman Pengembangan KTSP. Peraturanperaturan tersebut pada dasarnya memuat ide tentang kurikulum 2013, sehingga keduanya seharusnya dijadikan pedoman pengembangan KTSP oleh sekolah.
Sebagaimana dikemukakan oleh Hasan (2008:121) bahwa ide kurikulum merupakan komponen terpenting dalam proses pengembangan kurikulum.

Dalam pengembangan KTSP ide kurikulum perlu dipahami oleh tim pengembang kurikulum, sehingga pengembangan dokumen kurikulum yang disusun mencerminkan kesinambungan dengan ide kurikulum. Tanpa kejelasan ide kurikulum dimungkinkan terjadi ketidak sinambungan antara ide dan dokumen kurikulum. Hasan (2008:123) mengatakan bahwa kejelasan ide kurikulum sangat membantu tim pengembang dalam mengkonstruksi dokumen kurikulum. Pendapat Yani (2013:186) bahwa ide kurikulum setidaknya ada empat asas gagasan yang perlu dievaluasi yaitu asas filosofis, psikologi, sosiologis, dan organisatoris, karena itu ide dasar kurikulum perlu dievaluasi.

Pemahaman ide kurikulum 2013 sangat penting dipahami oleh kepala sekolah dan guru karena mereka merupakan tim pengembang kurikulum tingkat sekolah dan ujung tombak dalam mengembangkan KTSP. Ide Kurikulum 2013 merupakan komponen penting dalam mengembangkan KTSP, karena ide tersebut akan mewarnai dokumen yang dihasilkan, yaitu dokumen KTSP. Sehubungan dengan hal ini penulis berpijak pada pendapat Hasan (1988:28) bahwa ada empat dimensi kurikulum yang saling terkait, yaitu: (1) kurikulum sebagai ide 
atau konsepsi; (2) kurikulum sebagai rencana tertulis; (3) kurikulum sebagai proses; dan (4) kurikulum sebagai hasil belajar. Dari empat dimensi tersebut yang akan menjadi fokus penelitian adalah dimensi pertama dan kedua, yakni kurikulum sebagai ide dan kurikulum sebagai rencana tertulis atau dokumen kurikulum.

Permendikbud Nomor 61 Tahun 2014 tentang Pedoman Pengembangan KTSP Kurikulum 2013 (2013:3) bahwa komponen KTSP meliputi 3 dokumen, yakni dokumen 1 yang disebut dengan Buku I KTSP, dokumen 2 yang disebut dengan Buku II KTSP berisi silabus, dan dokumen 3 yang disebut dengan Buku III KTSP berisi rencana pelaksanaan pembelajaran. Berdasarkan pedoman tersebut maka satuan pendidikan/sekolah dalam mengembangkan dokumen KTSP meliputi tiga dokumen dimaksud. Pemahaman kepala sekolah dan guru tentang ide kurikulum 2013 akan mewarnai bagaimana dokumen I, dokumen II, dan dokumen III dikembangkan.

$\begin{array}{lrr}\text { Penelitian } & \begin{array}{r}\text { terdahulu } \\ \text { Kurikulum }\end{array} & \text { tentang } \\ \text { permasalahan } & \text { Ku13 }\end{array}$
sebagaimana dilaksanakan Sulfasyah (2013), Kuntarto (2014), Ruja dan Sukamto (2013), Setiabudi (2013), belum ada yang terfokus pada penelitian dimensi kurikulum sebagai ide. Oleh karena itu fokus penelitian yang akan dilaksanakan adalah penelitian tentang pemahaman kepala sekolah dan guru tentang ide Kurikulum 2013 dan konsistensinya terhadap dokumen KTSP. Masalah penelitian yang akan dikaji adalah sebagai berikut.

1. Apakah ide kurikulum 2013 dipahami oleh kepala sekolah dan guru selaku tim pengembang kurikulum tingkat sekolah?

2. Bagaimanakah konsistensi ide kurikulum 2013 dengan dokumen I KTSP?

3. Bagaimanakah konsistensi ide kurikulum 2013 dengan dokumen II KTSP?

4. Bagaimanakah konsistensi ide kurikulum 2013 dengan dokumen III KTSP?
5. Permasalahan apakah yang dihadapi kepala sekolah dan guru selaku tim pengembang kurikulum tingkat sekolah terkait dengan kurikulum 2013 dan pengembangan KTSP?

Studi dokumen dalam penelitian terbatas pada dokumen KTSP yakni Buku I, Buku II, dan Buku III kelas empat SD. Secara umum penelitian bertujuan untuk mendeskripsikan dan mengeksplorasi fenomena tentang pemahaman ide kurikulum 2013 dan konsistensinya terhadap dokumen KTSP jenjang Sekolah Dasar.

Manfaat teoritis penelitian diharapkan dapat memberikan bukti penguatan bahwa ide kurikulum merupakan komponen penting dalam pengembangan kurikulum dan menguji teori pengembangan kurikulum berbasis sekolah (school-based curriculum development). Selain itu diharapkan memiliki manfaat praktis sebagai dasar kebijakan dalam mengevaluasi dan menyempurnakan Kurikulum 2013, serta dapat dijadikan dasar kajian untuk penelitian lebih lanjut dalam memperdalam dan memperluas kajian.

\section{TINJAUAN PUSTAKA}

Pada umumnya kurikulum dipahami sebagai sejumlah mata pelajaran yang harus dipelajari oleh peserta didik (Zais, 1976:3), kurikulum adalah "a race course of subject matters to be mastered". Pandangan ini sangat dominan sampai saat ini dan masih banyak dijadikan dasar dalam mengembangkan kurikulum sehingga dalam sistem persekolahan, kurikulum tiap jenjang pendidikan memiliki sejumlah mata pelajaran yang harus dipelajari peserta didik.

Di Indonesia pengertian kurikulum ditetapkan dalam Undang-Undang Sisdiknas Nomor 20 Tahun 2003 dengan batasan kurikulum adalah seperangkat rencana dan pengaturan mengenai isi dan bahan pelajaran serta cara yang digunakan sebagai pedoman penyelenggaraan kegiatan belajar mengajar. Batasan tersebut 
dapat disimpulkan bahwa ada dua aspek dalam kurikulum, selain sebagai rencana (as a plan) yang menjadi pedoman dalam proses pelaksanaan pembelajaran oleh guru, juga merupakan pengaturan isi (scope dan sequence of content) dan cara pelaksanaan rencana (method and strategy of learning process). Keduanya berfungsi sebagai pedoman untuk mencapai tujuan pendidikan nasional.

Posisi kurikulum dalam sistem pendidikan merupakan komponen yang penting dan utama. Kurikulum sejatinya dihadirkan supaya menjadi alat utama agar pendidikan yang dijalankan selaras dengan cita-cita bangsa (Yamin; 2012:17). Soedijarto (2008) dalam Yamin (2012:36) mengatakan:

Sekolah merupakan lembaga sosial yang keberadaannya merupakan bagian dari sistem sosial Negara bangsa. Ia bertujuan untuk mencetak manusia susila yang cakap, demokratis, bertanggung jawab, beriman, bertakwa, sehat jasmani dan ruhani, memiliki pengetahuan dan keterampilan, kepribadian yang mantap dan mandiri. Pencapaian tujuan itu akan bisa diraih ketika ada suatu proses yang terencana dengan efisien, efektif, dan relevan. Agar tujuan tersebut tercapai maka dibutuhkan kurikulum yang kuat, baik secara infrastruktur maupun superstruktur.

Kurikulum sebagai komponen utama sistem pendidikan pada hakekatnya mencakup empat dimensi kurikulum yang saling terkait. Hasan (1988:28) empat dimensi kurikulum tersebut adalah: 1) kurikulum sebagai ide atau konsepsi; 2) kurikulum sebagai rencana tertulis; 3) kurikulum sebagai proses; dan 4) kurikulum sebagai hasil belajar. Kurikulum dalam dimensi ide atau konsepsi diartikan dalam kajian selanjutnya sebagai 'ide kurikulum 2013'. Kurikulum sebagai dimensi rencana tertulis diartikan seperangkat rencana tertulis (as a plan) atau dokumen kurikulum untuk dapat dijadikan pedoman dalam pelaksanaan pembelajaran atau diimplementasikan dalam pembelajaran (curriculum in action).
Istilah ide kurikulum menurut pendapat Hasan (2008:121) adalah merupakan rumusan dari posisi filosofis pendidikan yang dianut, pandangan teoritik tentang konsep kurikulum, model kurikulum yang digunakan, konsep tentang konten, organisasi kurikulum, desain kurikulum, desain dokumen kurikulum, posisi peserta didik dalam belajar. Pada dasarnya ide kurikulum 2013 dapat dipahami dari Permendikbud Nomor 54 Tahun 2013 tentang Standar Kompetensi Lulusan Pendidikan Dasar dan Menengah dan diperbarui melalui Permendikbud Nomor 20 tahun 2016, Permendikbud Nomor 64 Tahun 2013 tentang Standar Isi Pendidikan Dasar dan Menengah dan diperbarui melalui Permendikbud Nomor 21 Tahun 2016, Permendikbud Nomor 22 Tahun 2016 tentang Standar Proses, Permendikbud Nomor 23 Tahun 2016 tentang Standar Penilaian, Permendikbud Nomor 24 Tahun 2016 tentang Kompetensi Inti dan Kompetensi Dasar Pelajaran, serta Permendikbud Nomor 67 Tahun 2013 tentang Kerangka Dasar dan Struktur Kurikulum Sekolah Dasar/Madrasah Ibtidaiyah.

Sebagaimana tercantum dalam Undang-undang Nomor 20 Tahun 2003 bahwa pendidikan di Indonesia bertujuan untuk berkembangnya potensi peserta didik agar menjadi manusia yang beriman dan bertakwa kepada Tuhan Yang Maha Esa, berakhlak mulia, sehat, berilmu, cakap, kreatif, mandiri, dan menjadi warga negara yang demokratis serta bertanggung jawab.

Konsep kurikulum telah ditetapkan dalam Undang-Undang Sisdiknas Nomor 20 Tahun 2003, dengan batasan kurikulum adalah seperangkat rencana dan pengaturan mengenai isi dan bahan pelajaran serta cara yang digunakan sebagai pedoman penyelenggaraan kegiatan pembelajaran untuk mencapai tujuan pendidikan tertentu. Batasan tersebut dapat disimpulkan bahwa ada dua dimensi kurikulum, yang pertama adalah rencana (as a plan) dan pengaturan mengenai tujuan, isi, dan bahan pelajaran. Sedangkan yang kedua adalah cara 
pelaksanaan rencana (method and strategy of learning process).

Kurikulum 2013 termasuk kurikulum teknologis, karena kurikulum bukan hanya diarahkan pada pemeliharaan dan pengawetan ilmu tetapi diarahkan pada penguasaan kompetensi, sehingga disebutnya kurikulum berbasis kompetensi (KBK). Dalam kurikulum ini suatu kompetensi diuraikan menjadi kompetensi yang lebih khusus dan akhirnya menjadi perilaku-perilaku yang dapat diamati atau diukur.

Adapun pengertian kompetensi menurut Undang-undang Nomor 20 Tahun 2003 tentang Sisdiknas adalah kualifikasi kemampuan lulusan yang mencakup sikap, pengetahuan, dan keterampilan sesuai dengan standar nasional yang telah disepakati. Menurut Sanjaya (2008:131) kompetensi adalah perpaduan dari pengetahuan, keterampilan, nilai dan sikap yang direfleksikan dalam kebiasaan berpikir dan bertindak.

Konsep belajar, proses belajar, dan lingkungan belajar akan dipengaruhi oleh posisi filosofis kurikulum. Dalam Permendikbud Nomor 22 Tahun 2016 dikemukakan konsep tentang belajar, proses belajar, dan lingkungan belajar. Proses belajar adalah kriteria mengenai pelaksanaan pembelajaran pada satuan pendidikan untuk mencapai Standar Kompetensi Lulusan. Adapun belajar dalam kurikulum 2013 dikatakan bahwa belajar itu hanya dapat dilakukan oleh anak sendiri, bukan karena dipompakan ke dalam otaknya. Yang penting adalah bukan "what to think" melainkan "how to think" yakni melalui pemecahan masalah (Nasution; 2011:25). Pandangan ini adalah pandangan filosofi pragmatisme dan social reconstruktivism. Mengajar menurut constructivism bukanlah kegiatan memindahkan pengetahuan dari guru kepada siswa, melainkan suatu kegiatan yang memungkinkan siswa membangun sendiri pengetahuannya (Yamin; 2012:3).

Pendekatan pembelajaran yang ditetapkan dalam Permendikbud Nomor 22
Tahun 2016 adalah pendekatan ilmiah (scientific), tematik terpadu (tematik antar matapelajaran), dan tematik (dalam suatu mata pelajaran), untuk menunjang pendekatan tersebut perlu diterapkan pembelajaran berbasis penyingkapan/ penelitian (discovery /inquiry learning). Untuk mendorong kemampuan peserta didik menghasilkan karya kontekstual, baik individual maupun kelompok maka sangat disarankan menggunakan pendekatan pembelajaran yang menghasilkan karya berbasis pemecahan masalah (project based learning).

Konsep peserta didik dan peran guru dapat dipahami dari penjelasan dalam Permendikbud Nomor 20 Tahun 2016 tentang Standar Kelulusan dan Permendikbud Nomor 21 Tahun 2016 tentang Standar Isi. Selain itu dapat dipahami berdasarkan pendekatan pembelajaran Kurikulum 2013, yang dikenal dengan pendekatan saintifik. Pendekatan saintifik menurut Sufairoh (2016) adalah:

"Proses pembelajaran yang dirancang sedemikian rupa agar peserta didik secara aktif mengonstruk konsep, hukum atau prinsip melalui tahapan-tahapan mengamati (untuk mengidentifikasi atau menemukan masalah), merumuskan masalah, mengajukan atau merumuskan hipotesis, menganalisis data, menatik kesimpulan, dan mengkomunikasikan konsep, hukum atau prinsip yang ditemukan."

Ditjen Dikdasmen Kemendikbud (2013: 4) menjelaskan dimensi pembelajaran Kurikulum 2013 menekankan pada dimensi pedagogik modern dalam pembelajaran, yaitu menggunakan pendekatan ilmiah dalam pembelajaran sebagaimana dimaksud meliputi mengamati, menanya, mencoba, mengolah, menyajikan, menyimpulkan, dan menciptakan semua mata pelajaran. Menurut Permendikbud Nomor 22 Tahun 2016 tentang Standar Proses bahwa pendekatan saintifik ditempuh melalui "5M" yaitu mengamati, menanya, mengumpulkan data, mengasosiasi, mengkomunikasikanUntuk memperkuat pendekatan saintifik dilaksanakan 
pendekatan tematik terpadu pada jenjang Sekolah Dasar, dan model pembelajaran discovery/inquiry learning, problem-based learning, project-based learning. Pendekatan tematik terpadu menurut Kemendikbud (2013:7) adalah pembelajaran dengan memadukan beberapa mata pelajaran melalui penggunaan tema. Pada pembelajaran tematik terpadu peserta didik tidak mempelajari materi mata pelajaran secara terpisah semua mata pelajaran yang ada di sekolah dasar sudah melebur menjadi satu kegiatan pembelajaran yang diikat dengan tema.

Pembelajaran tematik berlandaskan psikologi gestalt, yang berpandangan bahwa belajar dimulai dengan sesuatu yang familiar dan setiap langkah dalam pendidikan didasarkan pada hal-hal yang sudah dikuasai. Semua aspek pelajaran dibagi menjadi unit-unit yang bermakna, dan unit-unit itu harus berkaitan dengan seluruh konsep atau pengalaman (Hergenahn dan Olson; 2008:307).

Konten Kurikulum 2013 mencakup standar isi yang ada dalam Permendikbud Nomor 64 Tahun 2013, terdapat Kompetensi Inti (KI), terdiri dari sikap, pengetahuan, dan keterampilan. Kompetensi sikap terdiri dari sikap spiritual dan sikap sosial, sikap dalam hal ini mengandung nilai karakter, oleh karena itu kurikulum 2013 sarat dengan muatan pendidikan karakter (Yani; 2013:55). Dalam hal ini dapat dikatakan bahwa content kurikulum 2013 adalah pendidikan karakter. Pendapat tentang pendidikan karakter sebagaimana dikemukakan Hendarman (2012:117) yang mengatakan: "Proses pendidikan karakter didasarkan pada totalitas psikologis yang mencakup seluruh potensi individu manusia (kognitif, afektif, psikomotor) dan fungsi totalitas sosiokultural dalam konteks interaksi dalam keluarga, satuan pendidikan, dan masyarakat."

Muatan kompetensi kurikulum 2013 untuk semua jenjang sama (Yani; 2013:56), yaitu menunjukkan perilaku yang mencerminkan sikap orang beriman, berakhlak mulia, berilmu, percaya diri, dan bertanggung jawab. Kompetensi kurikulum 2013 terdapat kompetensi generik untuk setiap mata pelajaran terdiri dari empat dimensi, yaitu sikap spiritual, sikap sosial, pengetahuan dan keterampilan. Kompetensi dikelompokkan menjadi dua, yaitu Kompetensi Inti dan Kompetensi Dasar Mata Pelajaran. Pada jenjang SD/MI proporsi sikap spiritual dan sosial lebih banyak dikembangkan daripada aspek pengetahuan dan keterampilan (Yani; 2013:91).

Berbicara desain kurikulum 2013 tergolong kurikulum subjek akademik. Karakteristik kurikulum subyek akademik adalah nama-nama mata pelajaran yang menjadi isi kurikulum hampir sama dengan nama disiplin ilmu, contohnya geografi, matematika, sejarah, biologi, fisika, kimia, ekonomi (McNeil, 1977:84-88). Organisasi isi kurikulum subjek akademik mengikuti pola correlated curriculum dan unified atau concentrated curriculum. Correlated curriculum adalah organisasi materi atau konsep dalam suatu disiplin ilmu atau mata pelajaran dikorelasikan dengan pelajaran lainnya, desain diwujudkan dalam bentuk pengelompokan mata pelajaran yang memiliki kedekatan, contohnya IPA, IPS. Unified atau concentrated curriculum adalah pola organisasi bahan pelajaran yang tersusun tema-tema pelajaran dan didalam tema tersebut mencakup materi dari berbagai bahan disiplin ilmu, hal ini terlihat dari kurikulum jenjang Sekolah Dasar. Evaluasi kurikulum subjek akademik menggunakan bentuk evaluasi bervariasi dan disesuaikan dengan tujuan dan sifat mata pelajaran. Variasi yang digunakan dalam bentuk tes uraian (essay test) dan tes obyektif (objective test).

Tugas sekolah dalam pengembangan kurikulum sesuai yang ditetapkan dalam Undang-undang Nomor 20 Tahun 2003 pasal 38 ayat (2), yaitu kurikulum pendidikan dasar dan menengah dikembangkan sesuai dengan relevansinya oleh setiap kelompok atau satuan pendidikan dengan komite 
sekolah/madrasah di bawah koordinasi dan supervise dinas pendidikan atau kantor departemen agama kabupaten/kota untuk pendidikan dasar dan provinsi untuk pendidikan menengah.

Ditegaskan dalam Permendikbud Nomor 61 Tahun 2014 bahwa kurikulum dikembangkan dengan prinsip diversifikasi, untuk melakukan penyesuaian program pendidikan pada satuan pendidikan dengan kondisi dan ciri khas potensi yang ada di daerah serta peserta didik. Dengan demikian tugas sekolah dalam pengembangan kurikulum adalah mengembangkan Kurikulum Tingkat Satuan Pendidikan (KTSP), dalam mengembangkan KTSP sekolah harus melibatkan komite sekolah.

KTSP dalam Undang-undang Sisdiknas dan Permendikbud Nomor 61 Tahun 2014 disebut dengan kurikulum operasional. Kurikulum operasional dikembangkan dan diimplementasikan oleh satuan pendidikan diwujudkan dalam bentuk KTSP. KTSP termasuk Schoolbased Curriculum Development (SBCD), menurut Lewy (1991) dalam Sulfasyah (2013:36) dapat didefinisikan secara luas dan sempit.

The broadest definitions implies that there is not only full autonomy for the school to decide what to teach, but also a commitment on its behalf to prepare instructional materials for the courses offered, with a minimal reliance on available textbooks. The narrow definitions of $S B C D$, on the other hand, indicates that the central education authority delegates some freedom to or grants some authority for the local or the school authorities to determine a certain part of the school program.

Hal ini sama halnya dengan kurikulum 2013, KTSP disusun oleh sekolah dan bernuansa SBCD. Oleh karena itu penyusunan KTSP harus bermakna (Yani; 2013:170) dengan lima ciri : (1) disusun sesuai prosedur; (2) dikembangkan oleh semua stakeholder; (3) dikaji dan dirumuskan sesuai poensi, kebutuhan, dan perkembangan peserta didik dan lingkungannya; (4) dilaksanakan sesuai dokumen KTSP; (5) dimonitor, dievaluasi, dan direvisi untuk ditingkatkan kinerjanya.

Komponen KTSP telah ditetapkan melalui Permendikbud Nomor 61 Tahun 2014 yang tercantum dalam Lampiran I, bahwa komponen KTSP meliputi tiga dokumen yaitu: Buku I KTSP, Buku II KTSP, dan Buku III KTSP. Buku I KTSP berisi sekurang-kurangnya visi, misi, tujuan, muatan, pengaturan beban belajar, dan kalender pendidikan. Buku II KTSP silabus pembelajaran. Dalam Lampiran Permendikbud Nomor 22 Tahun 2016 tentang Standar Proses dijelaskan bahwa silabus merupakan acuan penyusunan kerangka pembelajaran untuk setiap bahan kajian mata pelajaran. Silabus dikembangkan berdasarkan Standar Kompetensi Lulusan dan Standar Isi, digunakan sebagai acuan dalam pengembangan rencana pelaksanaan pembelajaran.

Adapun Buku III KTSP adalah Rencana Pelaksanaan Pembelajaran. Rencana Pelaksanaan Pembelajaran (RPP) adalah rencana kegiatan pembelajaran tatap muka untuk satu pertemuan atau lebih. RPP dikembangkan dari silabus untuk mengarahkan kegiatan pembelajaran peserta didik dalam upaya mencapai Kompetensi Dasar (KD). Komponen RPP sebagaimana tercantum dalam Permendikbud Nomor 22 Tahun 2014 meliputi kegiatan pendahuluan, kegiatan inti, dan kegiatan penutup.

Permendikbud Nomor 23 Tahun 2016 tentang Standar Penilaian, pengertian penilaian adalah proses pengumpulan dan pengolahan informasi untuk mengukur pencapaian hasil belajar peserta didik. Penilaian dalam Kurikulum 2013 pendidik harus mengutamakan assessment as learning dan assessment for learning. Assessment as learning merupakan penilaian yang menekankan pada keterlibatan peserta didik untuk secara aktif berpikir mengenai proses belajar dan hasil belajarnya sehingga berkembang menjadi pembelajar yang mandiri (independent learner). Assessment for learning adalah 
penilaian untuk mengidentifikasi kesulitan yang mungkin dihadapi peserta didik dan menemukan cara atau stratei untuk membantu peserta didik sehingga lebih, udah memahami dan membuat pembelajaran menjadi efektif.

Penilaian merupakan komponen kurikulum, dalam hal ini pengembangan KTSP baik dalam dokumen 1, dokumen 2, maupun dokumen 3 sudah harus dicantumkan rencana penilaian. Dalam merencanakan penilaian perlu dipahami Standar Penilaian sebagaimana ditetapkan melalui Permendikbud Nomor 23 Tahun 2016. Mengingat kurikulum 2013 berbasis kompetensi, maka penilaian yang dilaksanakan adalah capaian standar kompetensi yang berciri penilaian otentik. Penilaian otentik adalah penilaian yang nyata dan dibuktikan dengan kinerja dan atau hasil-hasil yang telah dibuat oleh peserta didik (Yani; 2013:145). Menurut Baron's yang dikutip Marzano dan dikutip ulang oleh Yani (2013:147) menentukan lima kriteria dalam merumuskan tugas penilaian otentik yaitu: (1) harus bermakna; (2) tugas disusun dengan melibatkan peserta didik; (3) menuntut peserta didik untuk aktif menemukan, menganalisis, dan menarik kesimpulan; (4) mensyaratkan untuk mengkomunikasikan hasil pekerjaan dalam melaksanakan tugas; (5) tugas mengharuskan untuk melakukan suatu perbuatan tertentu.

Penilaian pada jenjang SD/MI, walaupun pembelajarannya menggunakan pendekatan tematik terpadu, akan tetapi penilaian dilakukan dengan mengacu pada indikator dari Kompetensi Dasar setiap mata pelajaran yang diintegrasikan dalam tema. Tematik terpadu adalah pendekatan pembelajaran, hal yang berbeda dengan sistem penilaian. Karakteristik kurikulum 2013 adalah KBK sehingga kompetensi yang mencakup tiga ranah (sikap, pengetahuan, keterampilan) menjadi acuan penilaian.

\section{METODOLOGI PENELITIAN}

Sesuai tujuan penelitian maka pendekatan penelitian yang digunakan adalah penelitian kualitatif deskriptif eksploratori, yang bermaksud untuk menggambarkan dan mengungkap (to describe and explore) masalah penelitian (Sukmadinata; 2007:60). Lokasi penelitian di Kecamatan Sukalarang Kabupaten Sukabumi, populasi penelitian adalah semua SD berjumlah 15 sekolah. Sampel penelitian diambil dua sekolah, yakni SDN Sukalarang dan SDN Karamat. Desain penelitian dikembangkan sebagai berikut.

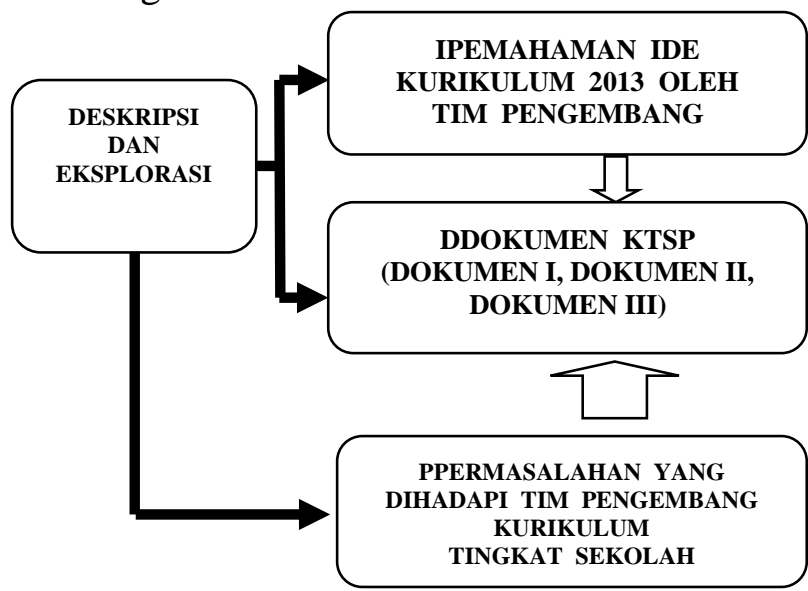

Gambar 1. Desain Penelitian

Variabel atau obyek penelitian (Sugiyono;2011:63) merupakan "simply defined a variable is a concept that varies" Neuman (2003:149) dalam penelitian ini meliputi pemahaman kepala sekolah dan guru tentang ide Kurikulum 2013, dokumen Buku I, II, dan III KTSP, dan permasalahan yang dihadapi kepala sekolah dan guru terkait dengan kurikulum 2013.

Definisi operasional ide kurikulum dalam penelitian ini merujuk pada pendapat Hasan (2008:12) yaitu rumusan dari posisi filosofis pendidikan yang dianut, pandangan teoritik tentang konsep kurikulum, model kurikulum yang digunakan, konsep tentang konten, organisasi kurikulum, desain kurikulum, desain dokumen kurikulum, posisi peserta didik dalam belajar. Dari pendapat tersebut setiap aspek dikaji sesuai yang termuat dalam Peraturan tentang Kurikulum 2013.

Dokumen KTSP yang dimaksud dalam penelitian meliputi tiga dokumen, 
yaitu Buku I KTSP, Buku II KTSP, dan Buku III KTSP. Buku I KTSP berisi sekurang-kurangnya visi, misi, tujuan, muatan, pengaturan beban belajar, dan kalender pendidikan. Buku II KTSP berisi silabus, dan Buku III KTSP berisi rencana pelaksanaan pembelajaran yang disusun sesuai potensi, minat, bakat, dan kemampuan peserta didik di lingkungan belajar.

Adapun permaslahan kurikulum 2013 dimaksudkan dalam penelitian adalah permasalahan yang dihadapi tim pengembang KTSP (kepala sekolah dan guru) berkaitan dengan: (1) penyusunan KTSP; (2) penyusunan silabus; (3) penyusunan RPP; dan (3) penyusunan sistem penilaian.

Teknik dan instrumen penelitian terdiri dari: (1) angket untuk mendapatkan data pemahaman tim pengembang KTSP (kepala sekolah dan guru) tentang ide kurikulum 2013; (2) pedoman studi dokumen digunakan untuk melakukan analisis konsistensi ide kurikulum 2013 terhadap dokumen KTSP; (3) pedoman focus group discussion (FGD) untuk membahas kedalaman pemahaman ide kurikulum 2013 oleh kepala sekolah dan guru dan konsistensi pemahaman ide Kurikulum 2013 dalam pengembangan dokumen KTSP serta permasalahan yang dihadapi berkaitan dengan Kurikulum 2013 (Kasali; 2008:295); (4) pedoman wawancara untuk menggali pendapat kepala sekolah tentang hasil analisis dokumen KTSP dan hasil FGD serta permasalahan yang dihadapi sekolah berkaitan dengan kurikulum 2013.

Teknik analisis data yang diterapkan mencakup tiga teknik, yaitu : (1) reduksi data untuk mengelompokkan unitunit analisis data berdasarkan permasalahan penelitian; (2) display data yaitu data penelitian yang telah direduksi disajikan dalam bentuk deskripsi sesuai permasalahan penelitian; (3) verifikasi dan penarikan kesimpulan dilakukan berdasarkan pemahaman terhadap data yang telah dikumpulkan disesuaikan dengan hakekat penelitian kualitatif.

Prosedur penelitian ditempuh melalui empat tahap, yakni; (1) tahap pendahuluan untuk melakukan penyusunan desain penelitian, studi pendahuluan ke lokasi penelitian, dan penyusunan kisi-kisi instrument; (2) pelaksanaan penelitian untuk pengumpulan data dengan menggunakan instrument angket, pedoman studi dokumen, FGD, dan wawancara; (3) tahap analisis data; (4) penyusunan laporan penelitian.

\section{HASIL PENELITIAN DAN PEMBAHASAN \\ Hasil Penelitian}

Hasil penelitian berikut diuraikan berdasarkan permasalahan penelitian. Pemahaman ide kurikulum 2013 Sekolah Dasar oleh kepala sekolah dan guru yang diperoleh menunjukkan semua responden membenarkan semua pernyataan yang tercantum dalam angket. Pernyataan dalam angket mencakup ide kurikulum 2013 meminta persetujuan "ya benar" atau "tidak tahu" dan semua responden yang berjumlah 23 orang, yakni dua orang kepala sekolah dan 21 orang guru menjawab "ya benar". Dalam hal ini dapat dikatakan bahwa responden mengaku memahami ide kurikulum 2013.

Hasil studi dokumen KTSP di dua sekolah dapat dijelaskan sebagai berikut. Ditemukan bahwa SDN Sukalarang telah menyusun dokumen Buku I KTSP. Substansi dalam dokumen secara umum sesuai dengan format minimal yang ditetapkan dalam Pedoman Pengembangan KTSP sebagaimana tercantum pada lampiran Permendikbud Nomor 61 Tahun 2014. Dalam dokumen tersebut berisi tentang visi misi sekolah, tujuan sekolah, muatan kurikulum, pengaturan beban belajar, dan kalender pendidikan.

Dokumen Buku I KTSP SDN Karamat berbeda dengan dokumen SDN Sukalarang. Penyusunannya masih berorientasi pada pedoman penyusunan KTSP tahun 2006. Demikian pula dalam latar belakang 
tercantum acuan penyusunan Buku I KTSP adalah Peraturan Pemerintah Nomor 19 Tahun 2005, bukan Permendikbud Nomor 61 Tahun 2014.

Dokumen silabus kelas empat SDN Sukalarang berisi identitas sekolah, kelas dan semester, tema pembelajaran, dan alokasi waktu untuk satu tema pembelajaran. Dalam pengembangan silabus format yang digunakan dalam bentuk tabel terdiri dari tiga kolom, yakni mata pelajaran dan kompetensi dasar, materi pembelajaran, dan kegiatan pembelajaran. Silabus disusun per-tema pembelajaran dan dirinci dalam kegiatan pembelajaran menjadi sub-sub tema.

Pengembangan format silabus tidak ada perbedaan antara SDN Sukalarang dan SDN Karamat. Format yang digunakan dalam bentuk tabel terdiri dari tiga kolom, yakni mata pelajaran dan kompetensi dasar, materi pembelajaran, dan kegiatan pembelajaran. Namun demikian, dokumen silabus SDN Karamat peneliti tidak menemukan identitas sekolah dan tema pembelajaran.

Buku III KTSP merupakan dokumen Rencana Pelaksanaan Pembelajaran (RPP). Dokumen RPP teridentifikasi dikembangkan mencakup identitas yang lengkap sesuai Permendikbud Nomor 22 Tahun 2016. Yang tidak teridentifikasi dalam RPP adalah variasi penggunaan metode pembelajaran yang ditetapkan dalam ide Kurikulum 2013, yakni problem based-learning, dan discovery learning.

Hasil studi dokumen buku III KTSP SDN Karamat teridentifikasi bahwa RPP dikembangkan mencakup identitas yang lengkap sesuai Permendikbud Nomor 22 Tahun 2016. Ditemukan hal yang sama sebagaimana RPP SDN Sukalarang, yakni dalam RPP adalah tidak tercantum variasi penggunaan metode pembelajaran yang ditetapkan dalam ide Kurikulum 2013, yakni problem based-learning, dan discovery learning.

Deskripsi hasil kegiatan FGD terangkum sebagai berikut.
1. Ide kurikulum 2013 pernah didengan dari kegiatan sosialisasi maupun pelatihan, tetapi hanya sebatas disinggung dan diberikan sepintas saja.

2. Penyusunan silabus dan RPP dibuat sesuai dengan pembekalan dalam pelatihan, dan sebatas memenuhi format minimal sebagaimana dicontohkan dalam pelatihan. Dalam pelatihan dikatakan bahwa dalam menyusun silabus dan RPP cukup memindahkan apa yang sudah ada dalam Buku Guru dan Buku Siswa.

3. Permasalahan yang dihadapi tentang Kurikulum 2013 adalah buku yang datangnya tidak sesuai dengan awal tahun pelajaran, dan kesulitan penulisan rapot dengan deskripsi karena murid banyak jumlahnya. Kalo pembelajaran tematik mengapa penilaian tidak tematik, tetapi penilaian kembali lagi penilaian tiap mata pelajaran.

Adapun hasil wawancara tersimpulkan sebagai berikut.

1. Landasan filosofis Kurikulum 2013 dibahas sepintas dalam materi umum saat pelatihan.

2. Pelatihan Kurikulum 2013 belum merata semua guru.

3. Dari pusat hanya disediakan buku guru dan buku siswa, bukan silabus atau contoh bentuk format silabus. Jadi guru menyusun silabus maupun RPP tinggal menyesuaikan dengan buku guru dan buku siswa.

4. Masalah penilaian Kurikulum 2013, kesulitan ada pada prosedur dan administrasi penilaian, kendalanya jumlah siswa. Pengadministrasian nilai itu tiap tema, begitu penulisan di rapot harus per mata pelajaran cukup rumit.

\section{Pembahasan Hasil Penelitian}

\section{Pemahaman Kepala Sekolah dan \\ Guru tentang Ide Kurikulum 2013}

Pemahaman kepala sekolah dan guru tentang ide Kurikulum 2013 baru sebatas tahu dan pernah mendengar. Latar belakang belum memahami ide Kurikulum 2013 secara konseptual disebabkan oleh berbagai 
faktor, antara lain: (1) kajian tentang ide Kurikulum 2013 dalam pelatihan hanya bersifat umum dan tidak detail; (2) pelatihan Kurikulum 2013 belum merata diikuti oleh guru; (3) dalam pelatihan atau sosialisasi tidak dikaji bahwa ide kurikulum memiliki konsistensi terhadap pengembangan dokumen KTSP; (4) rentang waktu pelatihan hanya satu sampai empat hari; (5) strategi pelatihan Kurikulum 2013 lebih bersifat "theory oriented" dan kurang praktik.

Upaya yang dilakukan oleh Kepala SD Inti selaku Ketua Gugus Sekolah telah dilaksanakan untuk dapat mendiseminasikan hasil pelatihan Kurikulum 2013, namun belum semua kepala sekolah dan guru memiliki komitmen sama untuk mensukseskan Kurikulum 2013. Kelambanan pengembangan kurikulum antara lain disebabkan guru-guru banyak yang lebih ingin berpegang pada yang telah ada, merasa lebih aman dengan praktik-praktik rutin dan tradisional daripada mencoba halhal baru yang memerlukan pemikiran dan usaha yang lebih banyak (Nasution;2011:3). Kepala sekolah dan guru belum berupaya menggali ide kurikulum 2013 melalui membaca literatur atau mendatangkan nara sumber ahli untuk memantapkan dan memperkuat pemahaman ide Kurikulum 2013. Upaya yang sudah dilakukan melalui pertemuan K3S dan KKG sudah tepat, namun demikian belum dilengkapi dengan menghadirkan nara sumber ahli sehingga informasi Kurikulum 2013 yang disampaikan sebatas apa yang diketahui dan dipahami oleh kepala sekolah atau guru yang sudah mengikuti pelatihan. Sedangkan ide kurikulum yang perlu dipahami adalah posisi filosofis pendidikan yang dianut, pandangan teoritik tentang konsep kurikulum, model kurikulum yang digunakan, konsep tentang konten, organisasi kurikulum, desain kurikulum, desain dokumen kurikulum, posisi peserta didik dalam belajar (Hasan; 2008:121).
2. Konsistensi Ide Kurikulum 2013 terhadap Dokumen Buku I, Buku II, Buku III KTSP

Hasil studi dokumen Buku I KTSP SDN Sukalarang dan SDN Karamat menunjukkan temuan tentang isi dokumen yang berbeda, dan terdapat temuan satu aspek yang cukup mendasar yakni perumusan visi SDN Sukalarang masih mengadopsi visi Kabupaten Sukabumi dan Dinas Pendidikan Kabupaten yang diadopsi adalah visi tahun 2011-2015.

Dokumen Buku I KTSP antara SDN Sukalarang dan SDN Karamat adalah, dokumen Buku I KTSP SDN Sukalarang menunjukkan bahwa dokumen disusun oleh Tim dan sudah sesuai dengan Pedoman Penyusunan KTSP Kurikulum 2013, substansi dokumen Buku I KTSP sesuai Pedoman Pengembangan KTSP dan Peraturan Mendikbud Nomor 61 Tahun 2014.

Dokumen Buku I KTSP SDN Karamat merupakan dokumen KTSP yang substansinya berisi Kurikulum 2006. Dalam dokumen Buku I KTSP tidak diungkap atau dijelaskan kelas berapa yang masih mengacu pada Kurikulum 2006 dan kelas berapa yang sudah mengacu pada Kurikulum 2013. Ketidakjelasan substansi dokumen Buku I KTSP SDN Karamat menjadi tidak bermakna, sedangkan ide Kurikulum 2013 berharap KTSP bermakna (Yani; 2013:170).

Dokumen Buku II KTSP SDN Sukalarang dan SDN Karamat disusun dengan bentuk format sama, terdiri dari tiga kolom yaitu: mata pelajaran dan kompetensi dasar, materi pembelajaran, dan kegiatan pembelajaran. Dokumen yang dipelajari tidak menemukan konsistensi ide Kurikulum 2013 terhadap dokumen Buku II KTSP, baik di SDN Sukalarang maupun SDN Karamat. Ide Kurikulum 2013 tentang silabus tercantum dalam Permendikbud Nomor 22 Tahun 2016, baik acuan pengembangan silabus maupun komponen silabus.

Dokumen Buku III KTSP SDN Sukalarang dan SDN Karamat sebagaimana 
studi dokumen menunjukkan bahwa RPP yang disusun secara umum sudah memenuhi komponen sebagaimana Permendikbud Nomor 22 Tahun 2016 tentang Standar Proses. Konsistensi ide Kurikulum 2013 tidak tercermin dalam perencanaan metode, media pembelajaran, dan sumber belajar. Dalam RPP metode belum menerapkan multi metode, media dan sumber belajar masih "text book oriented", sehingga ide Kurikulum 2013 penerapan model pembelajaran discovery learning dan problem based learning tidak tercermin dalam dokumen RPP.

\section{Permasalahan yang dihadapi Kepala Sekolah dan Guru tentang Kurikulum 2013}

Permasalahan yang dihadapi kepala sekolah dan guru, berdasarkan hasil FGD maupun wawancara, adalah masalah penilaian dalam Kurikulum 2013. Kesulitan yang dihadapi sebenarnya dalam peng-administrasian hasil penilaian. Pada saat penilaian pembelajaran sehari-hari dengan pendekatan tematik yang dinilai adalah capaian kompetensi dasar dalam satu tema, tetapi pada saat mengukur kompetensi pada ulangan semester kembali lagi pada mata pelajaran. Dan pada akhir semester hasil penilaian harus ditransfer kedalam buku rapot dan ditulis secara deskriptif.

\section{SIMPULAN DAN REKOMENDASI Simpulan}

Pemahaman kepala sekolah dan guru tentang ide Kurikulum 2013 baru pada taraf kenal dan tahu, pemahaman bahwa ide kurikulum memiliki konsistensi dalam pengembangan dokumen KTSP atau kurikulum sebagai rencana belum dimiliki.

Dokumen KTSP yang dikembangkan menunjukkan tidak ada konsistensi antara ide Kurikulum 2013 dengan dokumen Buku I KTSP, Buku II KTSP, dan Buku III KTSP. Demikian pula, antara ide Kurikulm 2013 dengan dokumen KTSP yang dikembangkan oleh Tim Pengembang Kurikulum Sekolah belum terjadi kesinambungan, sehingga substansi dokumen Buku I, Buku II, dan Buku III KTSP belum mencerminkan memuat ide Kurikulum 2013 secara utuh.

Permasalahan yang dihadapi kepala sekolah dan guru berkaitan dengan Kurikulum 2013 adalah masalah penilaian, baik berkaitan dengan teknik dan jenis penilaian maupun teknik pengadministrasian hasil penilaian. Perubahan tentang penulisan hasil belajar peserta didik dalam buku laporan pendidikan (rapot) secara deskriptif ditanggapi sebagai sesuatu yang merepotkan guru, dan ingin kembali pada pola lama.

\section{Rekomendasi}

Rekomendasi ditujukan kepada pengambil kebijakan, bahwa strategi pelatihan perlu diubah dari bersifat "theory oriented" kearah "practices oriented" dan perlu divariasikan pelaksanaannya di tingkat Kecamatan atau Gugus Sekolah serta ditingkatkan efektifitas pola pendampingan Kurikulum 2013.

Direkomendasikan bagi kepala sekolah dan guru bahwa dalam mendiseminasikan Kurikulum 2013 perlu didukung dengan menghadirkan nara sumber ahli pada saat kegiatan workshop, kegiatan K3S atau KKG, sehingga pemahaman ide Kurikulum 2013 yang belum terkaji dalam pelatihan di tingkat Provinsi atau Kabupaten dapat diperkuat dan dimantapkan pada saat kegiatan K3S dan KKG.

\section{DAFTAR PUSTAKA}

Hasan, S.H. (1988). Evaluasi Kurikulum. Jakarta: Departemen Pendidikan dan Kebudayaan, Direktorat Jenderal Pendidikan Tinggi.

Hasan, S.H. (2008). Evaluasi Kurikulum. Bandung: Kerjasama PT Rosda dan UPI Bandung.

Hendarman. (2012). Kebijakan Pendidikan di Indonesia. Surabaya: Jenggala Pustaka Utama. 
Hergenahn, B.R. and Olson, M.H. (2008). Theories of Learning. (Terjemahan Edisi ke Tujuh). Jakarta: Kencana Prenada Media Group.

Kasali, Rhenald. (2008). Metode-metode Riset Kualiatif dalam Public Relations \& Marketing Communications. Yogyakarta: Bentang Pustaka.

Kuntarto. E. (2014). Kajian Implementasi Kurikulum 2013 pada Pembelajaran Calistung di SD. Universitas Jambi: FKIP Prodi PGSD.

McNeil, J. D. (1977). Curriculum: Comprehensive Introduction (4th ed.). London: Scott, Foresman, \& Brown.

Nasution, S. (2011). Asas-asas Kurikulum. Jakarta: Bumi Aksara.

Neuman, W.L. (2003). Social Research Methods Qualitative and Quantitative Approach. New York: Pearson Education Inc.

Ruja \& Sukamto. (2013). Survey Permasalahan Implementasi Kurikulum Nasional 2013 Mata Pelajaran IPS SMP di Jawa Timur. Universitas Negeri Malang.

Sanjaya, Wina. (2008). Kurikulum dan

Pembeajaran, Teori dan Praktik Pengembangan Kurikulum Tingkat Satuan Pendidikan (KTSP). Jakarta: Kencana Predana Media Group.

Setiabudi, B. (2013). Strategi Guru dalam Menghadapi Kurikulum 2013 di SMA Negeri 2 Surakarta. Surakarta: SMAN 2.

Sufairoh. (2016). Pendekatan Saintifik \& Model Pembelajaran K-13. Jurnal Pendidikan Profesional, Volume 5 No. 3 Desember 2016 hal 116.

Sulfasyah. (2013). Investigating the Implementation of Indonesian KTSP (School-Based Curriculum) in The Teaching of Writing in Year Two. Perth, Western Australia:Cowan University

Sugiyono. (2011). Metode Penelitian Kombinasi. Yogyakarta: CV ALFABETA.
Sukmadinata. N. S. (2007). Metode Penelitian Pendidikan. Bandung: Rosdakarya.

Yamin, Moh. (2012). Panduan Manajemen Mutu Kurikulum Pendidikan, Panduan Lengkap Tata Kelola Kurikulum Efektif. Yogyakarta:DIVA Press.

Yani, Ahmad. (2013). Mindset Kurikulum 2013. Bandung: Alfabeta.

Zais, Robert S. (1976). Curriculum Principles and Foundations. New York:Harper \& Row Publisher.

\section{Pedoman, Peraturan, dan Perundang-} undangan:

Departemen Pendidikan Nasional. UndangUndang Nomor 20 Tahun 2003 tentang Sistem Pendidikan Nasional. Jakarta: Depdiknas.

Kementerian Pendidikan dan Kebudayaan. (2013). Peraturan Pemerintah Nomor 32 Tahun 2013 tentang Perubahan Kedua Peraturan Pemerintah Nomor 19 Tahun 2005 tentang Standar Nasional Pendidikan. Jakarta: Kemdikbud.

Kementerian Pendidikan dan Kebudayaan. (2013). Peraturan Menteri Pendidikan dan Kebudayaan Republik Indonesia Nomor 67 Tahun 2013 tentang Kerangka Dasar dan Struktur Kurikulum Sekolah dasar/Madrasah Ibtidaiyah. Jakarta: Kemendikbud.

Kementerian Pendidikan dan Kebudayaan. (2014). Peraturan Menteri Pendidikan dan Kebudayaan Nomor 57 Tahun 2014 tentang Kurikulum 2013 Sekolah Dasar/Madrasah Ibtidaiyah. Jakarta: Kemdikbud.

Kementerian Pendidikan dan Kebudayaan. (2014). Peraturan Menteri Pendidikan dan Kebudayaan Nomor 61 Tahun 2014 tentang Kurikulum Kurikulum Tingkat Satuan Pendidikan Dasar dan Pendidikan Menengah. Jakarta: Kemdikbud.

Kementerian Pendidikan dan Kebudayaan. (2016). Peraturan Menteri Pendidikan dan Kebudayaan Nomor 20 Tahun 2016 tentang Standar Kelulusan Pendidikan 
Dasar dan Menengah. Jakarta: Kemdikbud.

Kementerian Pendidikan dan Kebudayaan. (2016). Peraturan Menteri Pendidikan dan Kebudayaan Nomor 21 Tahun 2016 tentang Standar Isi Pendidikan Dasar dan Menengah. Jakarta: Kemdikbud.

Kementerian Pendidikan dan Kebudayaan. (2016). Peraturan Menteri Pendidikan dan Kebudayaan Nomor 22 Tahun 2016 tentang Standar Proses Pendidikan Dasar dan Menengah. Jakarta: Kemdikbud.

Kementerian Pendidikan dan Kebudayaan. (2016). Peraturan Menteri Pendidikan dan Kebudayaan Nomor 23 Tahun 2016 tentang Standar Penilaian Pendidikan. Jakarta: Kemdikbud.

Kementerian Pendidikan dan Kebudayaan (2016). Peraturan Menteri Pendidikan dan Kebudayaan Nomor 24 Tahun 2016 tentang Kompetensi Inti dan Kompetensi Dasar Pelajaran pada Kurikulum 2013 pada Pendidikan dasar dan Pendidikan Menengah. Jakarta: Kemdikbud 